\author{
Aneta Drabek \\ Biblioteka Uniwersytetu Śląskiego \\ Centrum Informacji Naukowej i Biblioteka Akademicka \\ Uniwersytet Śląski w Katowicach \\ e-mail: aneta.drabek@ciniba.edu.pl \\ (iD https://orcid.org/0000-0003-1269-9309

\section{Grażyna Razik} \\ Biblioteka Uniwersytetu Śląskiego \\ Centrum Informacji Naukowej i Biblioteka Akademicka \\ Uniwersytet Śląski w Katowicach \\ e-mail: grazyna.razik@ciniba.edu.pl \\ (iD https://orcid.org/0000-0001-9059-6183
}

\title{
Repozytorium RE-BUŚ \\ jako miejsce upowszechniania dorobku naukowego pracowników Uniwersytetu Śląskiego Komunikat
}

\begin{abstract}
Abstrakt: Ruch Open Access rozwija się i zyskuje zwolenników wśród autorów, redakcji czasopism i wydawców monografii. Zalety otwartego dostępu, takie jak zwiększenie widzialności dorobku czy wzrost cytowalności, sprawiają, że autorzy coraz chętniej publikują prace w Open Access, ale także sami szukają miejsc, gdzie można umieszczać otwarte teksty. Naprzeciw ich oczekiwaniom wychodzą twórcy repozytoriów gromadzących teksty i dane oraz udostępniających je szerokiemu gronu odbiorców. Celem tej pracy jest popularyzacja i promocja Repozytorium Uniwersytetu Śląskiego RE-BUŚ jako bazy, która służy zwiększaniu widzialności dorobku pracowników Uniwersytetu.
\end{abstract}

Słowa kluczowe: Creative Commons. Open Access. Repozytorium Uniwersytetu Śląskiego RE-BUŚ. Uniwersytet Śląski w Katowicach 


\section{Wstęp}

Prowadzenie badań naukowych oraz ich późniejsza publikacja w postaci artykułów czy monografii to tak naprawdę pierwszy etap uprawiania nauki. Drugi stanowi dotarcie z wynikami do osób zajmujących się tym samym zagadnieniem, czyli faktycznie włączenie tych wyników do obiegu naukowego. $Z$ uwagi na to, że literatury naukowej wciąż przybywa, temat rozpowszechniania informacji naukowych w ramach instytucji i poza nią jest często poruszany. Rozpowszechnianie to może być realizowane poprzez kanały informacyjne, takie jak: bibliograficzne bazy danych, pełnotekstowe bazy danych (w tym m.in. repozytoria i biblioteki cyfrowe), strony czasopism naukowych, media społecznościowe i inne. Potocznie mówi się, że dany tekst został znaleziony w internecie, jednak w przypadku literatury naukowej najczęściej oznacza to, iż umieszczono go w którymś z wiarygodnych źródeł elektronicznych, a nie na przypadkowych stronach. Rosnąca liczba tekstów naukowych oraz rozwój narzędzi wyszukiwawczych sprawiły, że znacznie bardziej atrakcyjne i częściej wykorzystywane są bazy pełnotekstowe lub bibliograficzne, bezpośrednio linkujące do stron, z których można pobrać kompletne teksty. Publikacje wymagające dalszych poszukiwań (np. w bibliotece czy archiwum) stają się mniej popularne, a często nawet pomijane $\mathrm{w}$ przygotowaniu przeglądu literatury.

Pisząc o bazach pełnotekstowych, nie sposób pominąć zagadnienia faktycznego dostępu do publikacji naukowych, który bardzo często jest płatny. Osoba zainteresowana może skorzystać z dostępu elektronicznego do takiego tekstu pod warunkiem prenumeraty bazy lub czasopism (np. przez instytucję) lub wykupienia indywidualnego dostępu do konkretnej publikacji. Wzrost cen sprawia, że instytucje czasem muszą rezygnować z przydatnego źródła tylko dlatego, że nie mają funduszy na jego zakup. Kryzys związany z brakiem możliwości dostępu do wyników badań doprowadził do powstania ruchu Open Access (OA). $\mathrm{Z}$ dostępem Open Access mamy do czynienia, gdy użytkownik może czytać, pobierać, drukować i przeszukiwać teksty bez ograniczeń prawnych, finansowych i technicznych, $\mathrm{z}$ wyjątkiem prawa autora do zachowania integralności pracy, uznania autorstwa i wykorzystania zgodnie z prawem (Budapest).

Ruch Open Access prężnie się rozwija, a otwartych publikacji wciąż przybywa. W bazie danych Web of Science Core Collection wśród publikacji z 2005 r. 15\% stanowiły teksty otwarte. Odsetek ten w kolejnych latach systematycznie rósł, w 2017 r. osiągając blisko 
$30 \%{ }^{1}$. Zwiększa się także liczba czasopism wydawanych w otwartym dostępie. UlrichsWeb ${ }^{\mathrm{TM}}$ Global Serials Directory, jedna z największych baz gromadzących dane o czasopismach wydawanych na całym świecie, podaje, że aktualnie ukazuje się około 76 tys. czasopism naukowych. Najbardziej znany katalog zbierający i weryfikujący dane o naukowych czasopismach OA - Directory of Open Access Journals (DOAJ) - odnotowuje ich obecnie blisko 13 tys. (stan na kwiecień 2019 r.) (Directory). Zapewne nie wszystkie otwarte czasopisma naukowe są tam odnotowa$n^{2}$, należy więc zakładać, że ta liczba jest większa.

Rozwój czasopism OA oraz wzrost świadomości autorów i członków redakcji miały wpływ na rozwój repozytoriów, w których deponowane są wyniki badań. Dzięki temu autorzy wiedzą, co mogą deponować, i tym chętniej angażują się w tworzenie instytucjonalnego repozytorium. Stanowi on swego rodzaju cyfrowy magazyn, w którym umieszczane i udostępniane są pełne teksty publikacji naukowych lub gromadzone zbiory danych. Liczba repozytoriów stale rośnie. Baza OpenDOAR, zbierająca informacje na ten temat, odnotowuje ich 4131 (OpenDOARStatistics) ${ }^{3}$. W Polsce najstarszym i największym cyfrowym magazynem jest Repozytorium Uniwersytetu im. Adama Mickiewicza AMUR (Karwasińska, Rychlik, 2010; Karwasińska, Rychlik, 2013). Wiele polskich repozytoriów korzystało i nadal korzysta z doświadczeń bibliotekarzy z Biblioteki Uniwersyteckiej w Poznaniu, którzy przetarli szlaki w tej działalności ${ }^{4}$. Celem niniejszego artykułu jest scharakteryzowanie Repozytorium RE-BUŚ oraz wskazanie jego roli w upowszechnianiu dorobku naukowego pracowników i studentów Uniwersytetu Śląskiego w Katowicach.

\section{Początki RE-BUŚ}

Pierwsze doświadczenia w zakresie umieszczania tekstów na platformie cyfrowej na Uniwersytecie Śląskim wiążą się z pracami nad współtworzeniem Śląskiej Biblioteki Cyfrowej (ŚBC), założonej przez

${ }^{1}$ Obliczenia własne na podstawie danych z bazy Web of Science Core Collection.

${ }^{2}$ Analiza polskich czasopism naukowych pozwoliła na zidentyfikowanie 896 czasopism, które deklarują wykorzystywanie jednej z licencji Creative Commons, natomiast baza DOAJ indeksuje ponad 400 polskich czasopism.

${ }^{3}$ Stan na 7 kwietnia 2019 r.

${ }^{4}$ Dziękujemy Paniom Małgorzacie Rychlik i Monice Theus z Uniwersytetu im. Adama Mickiewicza w Poznaniu oraz Pani Ewie Rozkosz za pomoc i udzielenie wskazówek, które okazały się bardzo pomocne przy tworzeniu Repozytorium RE-BUŚ. 
Bibliotekę Śląską w Katowicach i Uniwersytet Śląski w 2006 r. Podczas tych prac możliwe było zgłębienie zagadnień digitalizacji, tworzenia metadanych i tych dotyczących prawa autorskiego (Bratkowski, Lis, Szulc, red., 2017). Uniwersytet Śląski umieszcza w Śląskiej Bibliotece Cyfrowej wybrane prace naukowe i czasopisma wydawane przez Wydawnictwo Uniwersytetu Śląskiego oraz powstałe na uczelni prace doktorskie, których autorzy wyrazili na to zgodę. Analiza widoczności tych prac w wyszukiwarkach naukowych, takich jak Google Scholar czy BASE, pokazała, że bardzo rzadko pojawiają się w wynikach wyszukiwania lub też znaleźć je można na odległych stronach wyników. Na słabą widoczność miał wpływ fakt, że Śląska Biblioteka Cyfrowa gromadzi różnorodne materiały, w tym teksty literatury pięknej, rękopisy, mapy, pocztówki, księgi adresowe, prasę lokalną i wiele innych, które nie mają charakteru naukowego. Badania widzialności publikacji naukowych umieszczonych w ŚBC dowiodły, że Google Scholar jako wyszukiwarka naukowa praktycznie nie indeksuje zdeponowanych tam materiałów (lub robi to wybiórczo), pomimo dostosowania parametrów biblioteki cyfrowej w celu optymalizacji wyszukiwania. Inną przyczyną może być umieszczanie w bibliotece cyfrowej całych tomów tekstów zamiast poszczególnych fragmentów (rozdziałów czy artykułów) lub przygotowywanie zeskanowanych publikacji w formacie djvu, który nie jest już obsługiwany przez najpopularniejsze przeglądarki.

Tymczasem oczekiwania autorów tekstów i ich użytkowników wzrosły. To, że publikacja jest umieszczona gdziekolwiek w internecie, już nie wystarczy. Coraz ważniejszy staje się szybki i łatwy dostęp do niej. Użytkownicy z reguły nie znają wielu baz danych, bibliotek cyfrowych, katalogów czy repozytoriów. Najczęściej korzystają z przeglądarek internetowych i tam spodziewają się znaleźć interesujące ich teksty. Badania wskazują, że $80,9 \%$ polskich naukowców wskazało Google jako główne narzędzie pozyskiwania informacji o publikacjach. Większość z tych osób (71,3\%) szukała tylko na pierwszej stronie wyników, na drugą stronę docierało niespełna 4\% ankietowanych, a na trzecią - 1,6\% (Kolasa, 2017, s. 176). Z tych badań wynika, że projektanci baz danych powinni mieć na uwadze nie tylko przyjazny interfejs, ale przede wszystkim wdrożenie wszelkich narzędzi służących do odpowiedniego wypozycjonowania danej informacji w wynikach wyszukiwania. Nieindeksowanie baz danych w wyszukiwarkach może doprowadzić do tego, że o ich zawartości będzie wiedzieć jedynie wąskie grono bibliotekarzy.

Doświadczenia bibliotekarzy specjalizujących się w wyszukiwaniu informacji potwierdzają, że publikacje zamieszczone $\mathrm{w}$ repozytoriach 
są dobrze widoczne i wyświetlają się na pierwszych stronach wyników. Zalet repozytoriów jest znacznie więcej. Wśród nich wymienić można: - zwiększenie widzialności dorobku;

- indeksowanie bibliografii załącznikowych, co wpływa na podwyższenie wskaźnika cytowalności;

- łatwiejszy sposób na wykrycie plagiatu (programy antyplagiatowe porównują dany tekst $\mathrm{z}$ tekstami znajdującymi się w sieci);

- bezpieczną archiwizację danych;

- ograniczenie kosztów (nie ma konieczności drukowania kolejnych kopii);

- wzrost prestiżu uczelni i możliwość osiągnięcia wyższego miejsca w rankingach;

- wspieranie edukacji studentów (Rychlik, Karwasińska, 2007, s. 157159).

Analiza potencjalnych korzyści, a także oczekiwania władz uczelni sprawiły, że podjęto decyzję o utworzeniu repozytorium instytucjonalnego dla Uniwersytetu Śląskiego. Koordynacją wszelkich działań z tym związanych miała się zająć Biblioteka Uniwersytetu Śląskiego. Etap koncepcyjny został poprzedzony wyjazdem służbowym zaangażowanych w projekt tworzenia repozytorium pracowników do Biblioteki Uniwersyteckiej w Poznaniu i Biblioteki Dolnośląskiej Szkoły Wyższej we Wrocławius, gdzie poznawali oni działanie repozytoriów, aspekty prawne i techniczne oraz kwestie dotyczące współpracy z pracownikami naukowymi.

Prace rozpoczęły się od przygotowania koncepcji prezentującej podstawowe założenia dotyczące repozytorium. Opracowano wstępną propozycję struktury repozytorium UŚ, które miało zawierać publikacje naukowe i popularnonaukowe pracowników, doktorantów i studentów Uniwersytetu. Wszystkie opublikowane prace miały być „otwarte”. Zapadła też decyzja odnośnie do oprogramowania - wybrano najczęściej używane w polskich i światowych repozytoriach otwarte oprogramowanie DSpace.

Pod koniec listopada 2016 r. do Ministerstwa Nauki i Szkolnictwa Wyższego został złożony wniosek o finansowanie działalności upowszechniającej naukę. Jeden $\mathrm{z}$ punktów zgłoszonych w ramach zadania 3. „udostępnianie zasobów bibliotecznych w formie elektronicznej” obejmował finansowanie repozytorium Uniwersytetu Śląskiego.

${ }^{5}$ Wyjazd odbył się w dniach 25-26 października 2016 r. Wzięli w nim udział bibliotekarze z Biblioteki Uniwersytetu Śląskiego: Grażyna Razik, Aneta Drabek i Andrzej Koziara. 
W kwietniu 2017 r. ogłoszono wyniki tego konkursu, a wśród projektów ocenionych pozytywnie znalazł się projekt dotyczący RE-BUŚ. Wniosek uzyskał częściowe wsparcie finansowe, które obejmowało umieszczenie $\mathrm{w}$ repozytorium 1000 publikacji ${ }^{6}$. W związku z tym wystosowana została prośba do władz Uniwersytetu Śląskiego o przyznanie środków na wdrożenie oprogramowania, zaprojektowanie logo i wsparcie techniczne projektu. Po uzyskaniu zapewnienia o przyznaniu odpowiedniej kwoty rozpoczęły się prace techniczne. Równocześnie przygotowywano zarządzenie w sprawie utworzenia Repozytorium ( $\mathrm{Za}$ rządzenie, 2018), regulamin korzystania $z$ niego oraz zasób przydatnych informacji dotyczących zagadnień prawnych i ustalania praw do publikacji. Powstała wówczas również oficjalna nazwa - Repozytorium Uniwersytetu Śląskiego w Katowicach (RE-BUŚ).

Pod koniec 2017 r. można było zaprezentować Repozytorium społeczności akademickiej. Powstał zrąb główny - 14 kolekcji głównych podzielonych na podkolekcje. Przyjęto, że prace będą deponowane bezpośrednio przez autorów prac (pracowników, doktorantów i studentów Uniwersytetu Śląskiego) albo przez redaktorów-bibliotekarzy. Procedura obejmuje 2 etapy: deponowanie publikacji oraz sprawdzenie rekordu i zatwierdzenie go przez redaktora. Dodatkowo każda zarchiwizowana publikacja ma być uzupełniana o tzw. stronę informacyjną (rys. 1), zawierającą następujące elementy: tytuł, nazwiska i imiona autorów, opis bibliograficzny, licencja, na jakiej została zdeponowana praca. Za tą decyzją przemawiało kilka względów. Po pierwsze, ma ona charakter promocyjny. Osoby, które dotrą do pliku nie bezpośrednio przez stronę RE-BUŚ, ale poprzez wyszukiwarkę, otrzymają informację, że pobrały plik z instytucjonalnego repozytorium. Jest to gwarancja wiarygodności pobranego tekstu. Drugi powód to uzupełnienie pliku o opis bibliograficzny publikacji. W większości współcześnie wydawanych czasopism na stronie tytułowej każdego artykułu, oprócz nazwiska autora i tytułu, dodawane są informacje o czasopiśmie, a także tom, numer, zakres stron czy identyfikator DOI. Taki plik z artykułem zawiera więc informacje wystarczające do przygotowania prawidłowego opisu bibliograficznego. Wiele starszych czasopism czy rozdziałów z monografii takich informacji nie posiada, a dodanie ich do pliku ułatwia korzystanie z publikacji i jej prawidłowe cytowanie.

${ }^{6}$ Utworzenie Repozytorium Uniwersytetu Śląskiego w Katowicach (RE-BUŚ) było współfinansowane ze środków Ministerstwa Nauki i Szkolnictwa Wyższego (Umowa nr 645/P-DUN/2017). 


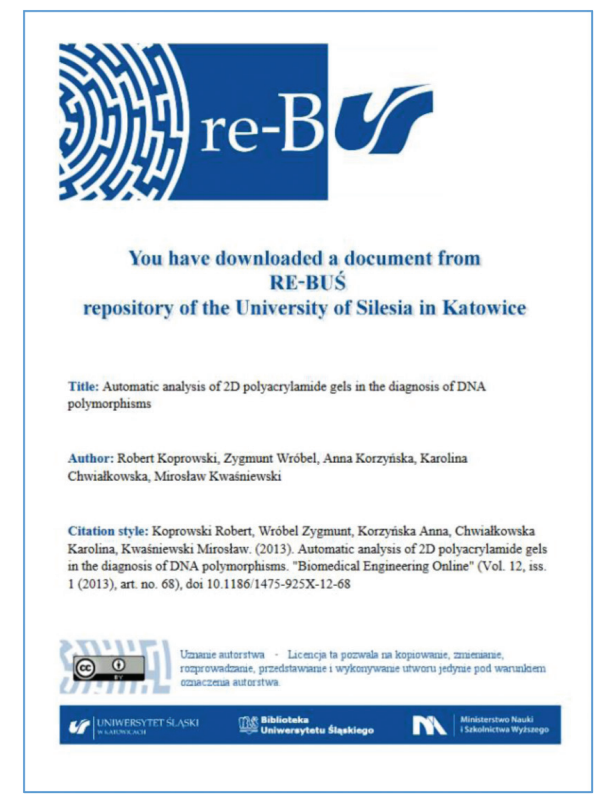

Rys. 1. Przykładowa strona informacyjna Źródło: (https://rebus).

Pierwszy etap zamieszczania pracy w RE-BUŚ to jej deponowanie. Proces ten jest prosty - polega na wypełnieniu formularza, gdzie należy podać niezbędne metadane: nazwiska i imiona autorów, tytuł, dane dotyczące źródła (czasopismo, monografia lub materiały konferencyjne), datę publikacji, identyfikatory (ISSN, ISBN, DOI), typ publikacji (artykuł, rozdział, monografia, prezentacja itd.), a także charakterystykę treściową w postaci słów kluczowych i abstraktu. Po wpisaniu danych osoba deponująca musi załączyć plik w formacie pdf, wybrać odpowiednią licencję (jedna z licencji Creative Commons lub licencja autora) i zaakceptować oświadczenie, w którym potwierdza, że ma prawa do publikowanego dzieła.

Drugi etap należy do redaktora, który przegląda metadane $\mathrm{i}$ - jeśli to konieczne - uzupełnia je. Następnie sprawdza, czy dana praca została opublikowana zgodnie z zadeklarowaną licencją i, w razie wątpliwości, kontaktuje się z autorem. Czasem konieczna jest również korekta graficzna zeskanowanego pliku i automatyczne optyczne rozpoznanie tekstu, czyli proces umożliwiający dodanie do pliku (składającego się z obrazów) warstwy tekstowej danej publikacji. Te działania poprawiają jakość pliku i sprawiają, że możliwe jest jego przeszukiwanie. Ostatnią czynność stanowi przygotowanie strony informacyjnej i dodanie jej do pliku. 
Biblioteka Uniwersytetu Śląskiego gromadzi i opracowuje doktoraty, dlatego ustalono, że prace osób, które wyraziły pisemną zgodę na publikację w otwartym dostępie, umieszczać będą w RE-BUŚ redaktorzy.

Przygotowane zostały instrukcje deponowania prac oraz udostępniania ich na licencji Creative Commons. Oba wymienione dokumenty oraz inne akty prawne ( $\mathrm{w}$ tym zarządzenie $\mathrm{w}$ sprawie utworzenia Repozytorium) zostały zamieszczone na stronie Centrum Informacji Naukowej i Biblioteki Akademickiej', a następnie udostępnione na stronie Repozytorium.

Oficjalne uruchomienie Repozytorium Uniwersytetu Śląskiego nastąpiło 23 lutego $2018 \mathrm{r}$.

\section{Opis repozytorium}

Repozytorium Uniwersytetu Śląskiego RE-BUŚ ${ }^{8}$ zostało umieszczone w domenie Uniwersytetu Śląskiego i zaprojektowane w kolorystyce zgodnej z kolorami uczelni. Ma ono budowę hierarchiczną. Utworzono 12 działów głównych, odpowiadających wydziałom Uniwersytetu Śląskiego, dział przypisany jednostkom ogólnouczelnianym i międzywydziałowym oraz zespół bibliotek Uniwersytetu Śląskiego. Każdy z działów został podzielony na 5 takich samych kolekcji: artykuły, książki i rozdziały, materiały dydaktyczne, materiały konferencyjne i rozprawy doktorskie. W Repozytorium zarejestrowano dotychczas 257 użytkowników.

Do 8 kwietnia 2019 r. w RE-BUŚ znalazło się 8510 publikacji, w tym:

- 4363 artykuły;

- 3408 książek i rozdziałów;

- 3 materiały dydaktyczne;

- 47 materiałów konferencyjnych;

- 689 prac doktorskich.

Prace deponowane w RE-BUŚ, oprócz podstawowych metadanych, obowiązkowo uzupełniane są o słowa kluczowe i abstrakty. Każdy plik $\mathrm{w}$ procesie zatwierdzania publikacji zaopatrzony jest $\mathrm{w}$ identyfikator URI Handle System, dzięki czemu dokument ma stałe miejsce w sieci. Wszystkie publikacje są dostępne w ramach otwartego dostępu i odpowiednio oznakowane wykorzystaną licencją Creative Commons lub inną.

\footnotetext{
${ }^{7} \mathrm{http}: / /$ ciniba.edu.pl/repozytorium-re-bus.

${ }^{8}$ https://rebus.us.edu.pl.
} 
Metadane o publikacjach umieszczonych w Repozytorium są pobierane przez takie agregatory, jak CEON, a także przez wyszukiwarkę BASE (Bielefeld Academic Search Engine). Po niespełna roku działalności RE-BUŚ jest na szóstym miejscu wśród zgłoszonych do CEON repozytoriów instytucjonalnych pod względem liczby zdeponowanych prac. Metadane z Repozytorium RE-BUŚ są także wykorzystywane przez multiwyszukiwarkę EBSCO Discovery Service, co pozwala na poszerzenie możliwych wyników wyszukiwania. Repozytorium zostało zarejestrowane $\mathrm{w}$ światowych katalogach repozytoriów (OpenDOAR i ROAR). Jest również widoczne w Google Scholar (GS), który przeszukuje strony naukowe i edukacyjne oraz naukowe bazy danych i stanowi jedno z podstawowych źródeł przeznaczonych do wyszukiwania literatury naukowej.

Dzięki wbudowanym statystykom DSpace autorzy prac umieszczonych w Repozytorium mogą śledzić statystyki odwiedzin swoich prac, czyli:

- liczbę wszystkich odwiedzin;

- liczbę odwiedzin w poszczególnych miesiącach;

- liczbę odwiedzin z poszczególnych krajów i miast;

- liczbę pobranych plików.

Od uruchomienia Repozytorium publikacje w nim umieszczone zostały wyświetlone ponad $1 \mathrm{mln} 660$ tys. razy. Istnieje również możliwość śledzenia statystyk poprzez Google Analytics. Dzięki nim wiadomo, że w ciągu 13 miesięcy RE-BUŚ doczekał się ponad 20 tys. odsłon. $\mathrm{Na}$ wykresie 1 pokazano liczbę odsłon w poszczególnych miesiącach.

\section{Liczba odsłon}

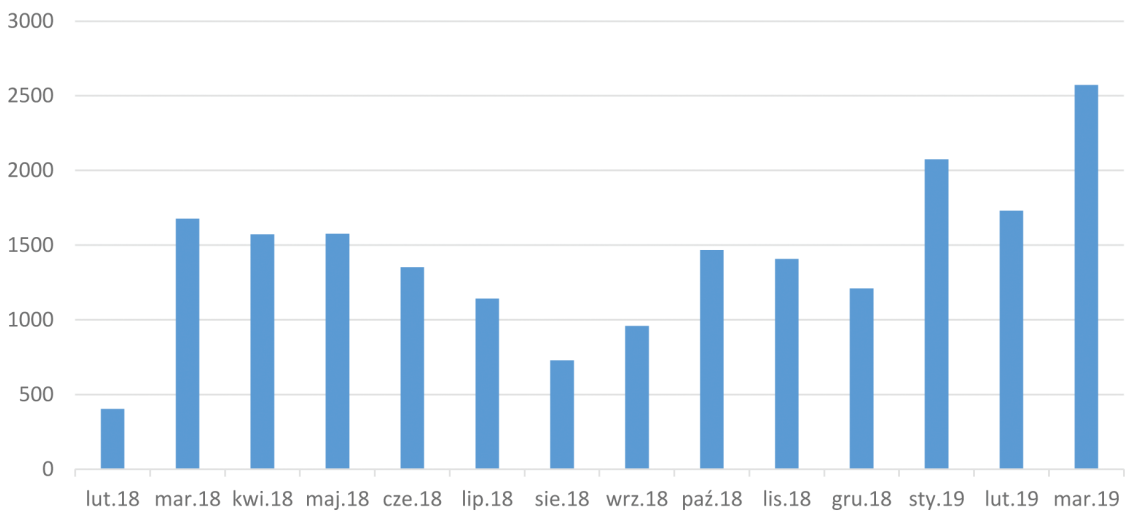

Wykres 1. Liczba odsłon Repozytorium RE-BUŚ (23.02.2018-31.03.2019)

Źródło: Obliczenia własne na podstawie Google Analytics. 


\section{Promocja}

Jeszcze przed oficjalnym uruchomieniem Repozytorium w jego bazie umieszczono kilkaset publikacji. Chodziło o to, żeby zachęcić autorów do czynnego uczestniczenia we współtworzeniu RE-BUŚ. Poza tym istotne było pokazanie, że publikacje te stosunkowo szybko trafiają do obiegu naukowego i są widoczne w Google Scholar. Działania promocyjne w pierwszym etapie skupiały się na tym, żeby naukowcy Uniwersytetu Śląskiego dowiedzieli się, że Repozytorium zostało otwarte i do czego ma służyć. Prorektor ds. badań naukowych prof. Andrzej Noras przesłał do wszystkich pracowników e-mail z informacjami dotyczącymi RE-BUŚ. W „Gazecie Uniwersyteckiej UŚ” ukazał się krótki artykuł o Repozytorium (Witek, 2018). Utworzono również konta w mediach społecznościowych (Facebook i Twitter), na których promowane są wybrane publikacje zdeponowane w RE-BUŚ. Prace pobrane z Repozytorium są umieszczane przez niektórych naukowców w innych serwisach, takich jak ResearchGate czy Academia.edu. Repozytorium promują też pająki (rys. 2), które na plakacie zaprojektowanym przez Michała Tomaszka przekonują, że deponowanie zwiększa widoczność w sieci.

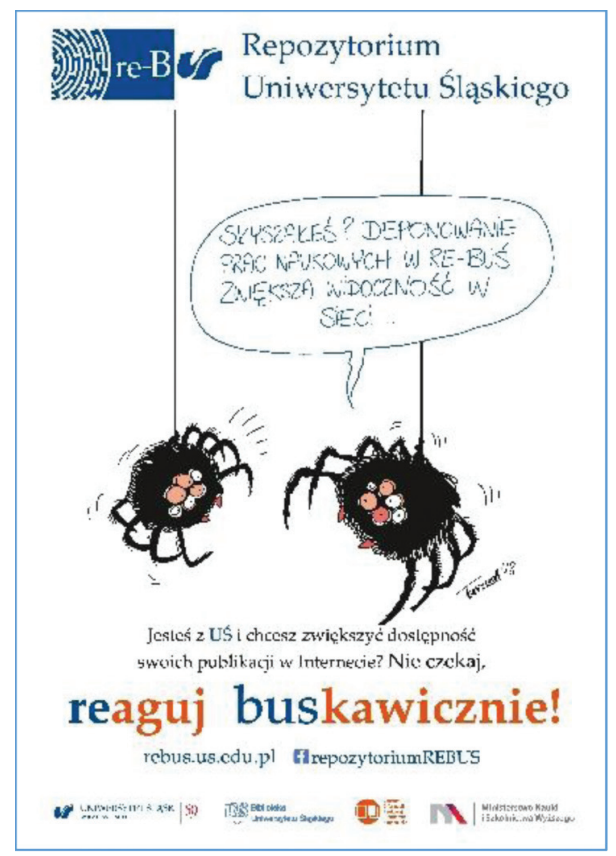

Rys. 2. Projekt plakatu reklamującego RE-BUŚ

Źródło: Autor plakatu: Michał Tomaszek. 
Wiosną 2018 r. odbyły się spotkania z pracownikami Uniwersytetu Śląskiego, które stanowiły okazję do upowszechniania idei Open Access, przedstawiania zalet otwartego publikowania, a także kwestii związanych z prawem autorskim. Poruszane na spotkaniach zagadnienia dotyczące majątkowych praw autorskich okazały się bardzo ważne, ponieważ nieznajomość prawa autorskiego powstrzymuje autorów przed samodzielnym deponowaniem.

\section{Sposoby pozyskiwania tekstów}

Oprócz zachęcania społeczności akademickiej Uniwersytetu Śląskiego do samodzielnego deponowania prac podjęte zostały działania mające na celu pozyskiwanie tekstów do opracowania przez redaktorów. Nawiązana została współpraca z Wydawnictwem Uniwersytetu Śląskiego polegająca na tym, że Biblioteka UŚ otrzymuje monografie naukowe, które można zdeponować w Repozytorium 18 miesięcy po ich publikacji. Wszystkie te prace umieszczone są na licencji Creative Commons (CC BY-NC-ND 4.0 - Uznanie autorstwa - Użycie niekomercyjne - Bez utworów zależnych 4.0 Międzynarodowe). Artykuły z czasopism wydawanych przez Wydawnictwo Uniwersytetu Śląskiego mogą być umieszczane przez redaktora Repozytorium (ale także przez samych autorów) na wspomnianej licencji natychmiast, bez embarga. $\mathrm{W}$ ten sposób w RE-BUŚ znalazły się wszystkie teksty pracowników Uniwersytetu Śląskiego wydane w ramach serii „Prace Naukowe Uniwersytetu Śląskiego" w latach 2009-2016. Umowy wydawnicze, jakie obowiązywały od 2009 r., nie wymagały proszenia autorów o zgodę. Aby poszerzyć zasób Repozytorium o wcześniejsze prace wydane w ramach „Prac Naukowych Uniwersytetu Śląskiego”, podjęto decyzję dotyczącą pozyskiwania zgód autorskich. Na postawie danych zgromadzonych w prowadzonej przez Bibliotekę Uniwersytetu Śląskiego Bibliografii Dorobku Pracowników UŚ przygotowane zostały informacje o monografiach i rozdziałach poszczególnych pracowników. Zwrócono się do autorów z prośbą o wyrażenie zgody na umieszczenie tych tekstów w otwartym repozytorium instytucjonalnym. Odpowiedzi zebrane dotychczas z Wydziału Filologicznego, największego wydziału UŚ, pozwalają wnioskować, że propozycja spotkała się z zainteresowaniem i warto skierować takie prośby także do pracowników innych jednostek. Starsze prace pracowników Uniwersytetu Śląskiego z pewnością mogą stanowić unikatowy zasób, który nie był dostępny w sieci lub był obecny szczątkowo. Umieszczenie w Repozytorium wersji elektronicznej prac 
dostępnych do tej pory jedynie $\mathrm{w}$ wersji tradycyjnej pozwoli na ich ponowne włączenie do obiegu naukowego.

Bibliografia Dorobku Pracowników UŚ stanowi dla redaktorów Repozytorium także źródło informacji o pracach naukowych opublikowanych na otwartych licencjach. Teksty te umieszczane są równolegle w RE-BUŚ. Polityka gromadzenia danych do Bibliografii zakłada, że każdą publikację zgłaszaną tam jako Open Access od razu wprowadza się do Repozytorium. W Bibliografii umieszczany jest link do RE-BUŚ, co sprawia, że linki w Bibliografii są stabilne i nie wymagają ciągłych weryfikacji. To ważne, bo z badań wynika, że dostępność adresów WWW prowadzących do publikacji maleje i po 5-6 latach może wynieść około 50-60\% (Roszkowski, Włodarczyk, 2016, s. 31).

Jeśli w trakcie przeszukiwania baz danych, otwartych czasopism lub innych repozytoriów redaktorzy RE-BUŚ odnajdą otwarty tekst autorów z Uniwersytetu Śląskiego, takie prace są pobierane i deponowane w RE-BUŚ. W tym samym celu założono także alerty w bazach danych (Scopus oraz Web of Science Core Collection), które pozwalają na śledzenie nowych otwartych publikacji afiliowanych do Uniwersytetu Śląskiego.

Zespół RE-BUŚ pomaga autorom, którzy chcą samodzielnie umieścić tekst, w digitalizacji i przygotowaniu plików w formacie pdf. Wobec trudności w ocenie stanu prawnego publikacji redaktorzy służą pomocą w ustaleniu praw do niej, często także pytają o zgodę wydawcę czy redakcję czasopisma.

\section{Plany na przyszłość}

W ciągu roku redaktorom Repozytorium udało się zrobić bardzo wiele. Uruchomili Repozytorium Uniwersytetu Śląskiego, ale też wprowadzili ponad 8,5 tys. publikacji. Ważne jest dalsze pozyskiwanie prac, które będzie można umieścić w Repozytorium. Wśród nich będą na pewno prace najnowsze, ale też starsze, o ile uda się uzyskać zgodę autora lub właściciela majątkowych praw autorskich.

Równolegle planowane są kolejne spotkania z pracownikami i studentami Uczelni. Będą one dotyczyły zagadnień związanych z upowszechnianiem idei otwartego publikowania, zaletami publikowania w instytucjonalnym repozytorium (np. wzrost cytowalności). Jako że wciąż niewielu pracowników ma konta w RE-BUŚ ( $257 \mathrm{z}$ około 2 tys. pracowników naukowych UŚ), warto zachęcać pozostałych do ich zakładania i samodzielnego deponowania swoich tekstów. Chodzi też o to, żeby pracownicy nie bali się publikować w Open Access i świadomie 
wybierali czasopisma lub wydawców oferujących taki model publikacyjny. Dzięki Repozytorium Uniwersytetu Śląskiego RE-BUŚ wyniki badań prowadzonych na Uniwersytecie Śląskim mają szansę trafić do szerokiego grona odbiorców i służyć naukowcom na całym świecie.

1 października 2018 r. zaczęła obowiązywać nowa ustawa o szkolnictwie wyższym. Wraz z nią uległy zmianie pozostałe akty wykonawcze, $\mathrm{w}$ tym rozporządzenie w sprawie ewaluacji jakości działalności naukowej. I choć w rozporządzeniu tym nie ma mowy ani o repozytoriach, ani o Open Access (choćby w kontekście raportowania odpowiednich danych do baz centralnych, takich jak Polska Bibliografia Naukowa, jak miało to miejsce w ocenie parametrycznej przeprowadzonej w 2017 r.), to kwestia utrzymywania i rozwijania Repozytorium wydaje się bezsporna. Zespół Repozytorium UŚ stawia sobie za cel bieżące deponowanie wszystkich publikacji Open Access przygotowywanych przez pracowników i studentów Uniwersytetu. Informacje zgromadzone w RE-BUŚ są przekazywane do Bibliografii Dorobku Pracowników UŚ, a stamtąd do Polskiej Bibliografii Narodowej oraz Portalu Pracownika UŚ (wewnętrznej bazy Uniwersytetu, w której tworzone są potrzebne raporty i zestawienia dla władz). Dane na temat prac w otwartym dostępie staną się elementem oceny pracowników, będą także wykorzystywane podczas opracowywania dokumentów (np. Sprawozdania Rektora z działalności UŚ) czy ankiet.

\section{Literatura}

Bratkowski, P., Lis, R., Szulc, M. (red.). (2017). Cyfrowa pamięć regionu, 10 lat Śląskiej Biblioteki Cyfrowej. Katowice: Biblioteka Śląska.

Budapest Open Access Initiative [BOAI]. (2002). Pobrane z: https://www. budapestopenaccessinitiative.org/read (7.04.2019).

Directory of Open Access Journals [DOAJ]. 2019. Pobrane z: https://doaj.org/ (2.01.2019).

https://rebus.us.edu.pl/handle/20.500.12128/233.

Karwasińska, E., Rychlik, M. (2010). AMUR - Repozytorium Uniwersytetu im. Adama Mickiewicza. Pobrane z: https://repozytorium.amu.edu.pl/handle/ 10593/202 (2.01.2019).

Karwasińska, E., Rychlik, M. (2013). Doświadczenia z funkcjonowania pierwszego w Polsce repozytorium instytucjonalnego na Uniwersytecie im. Adama Mickiewicza w Poznaniu. W: Repozytoria i biblioteki cyfrowe c.d. Tworzenie i archiwizowanie zasobów, XXI edycja seminarium w cyklu 
digitalizacja, 5 czerwca 2013, Warszawa. Pobrane z: https://repozytorium. amu.edu.pl/handle/10593/6498 (2.01.2019).

Kolasa, W.M. (2017). Polskie czasopisma humanistyczne w perspektywie SEO. W: E. Kulczycki (red.), Komunikacja naukowa w humanistyce (175-210). Poznań: Wydawnictwo Naukowe Instytutu Filozofii UAM.

OpenDOAR Statistics. Pobrane z: http://v2.sherpa.ac.uk/view/repository_visu alisations/1.html (7.04.2019).

Roszkowski, M., Włodarczyk, B. (2016). Cytowania zasobów sieciowych w polskich czasopismach z zakresu bibliotekoznawstwa i informatologii, analiza aktualności adresów URL. Zagadnienia Informacji Naukowej - Studia Informacyjne, 1, 21-43.

Rychlik, M., Karwasińska, E. (2007). Repozytorium instytucjonalne jako czynnik wspomagający rozwój nauki w środowisku akademickim. Biblioteka, 11, 153-167.

Witek, J. (2018). Upowszechnianie dorobku naukowego. Gazeta Uniwersytecka UŚ, 7, 12.

Zarządzenie z dnia 19.02.2018 r. Rektora UŚ w sprawie utworzenia Repozytorium Uniwersytetu Śląskiego w Katowicach (RE-BUŚ). Pobrane z: http:// bip.us.edu.pl/zarzadzenie-nr-212018 (7.04.2019).

Tekst $w$ wersji poprawionej wptyną do redakcji 23 kwietnia 2019 r. 


\title{
Aneta Drabek
}

University of Silesia Library

Scientific Information Centre and Academic Library

University of Silesia in Katowice

e-mail: aneta.drabek@ciniba.edu.pl

(iD https://orcid.org/0000-0003-1269-9309

\section{Grażyna Razik}

University of Silesia Library

Scientific Information Centre and Academic Library

University of Silesia in Katowice

e-mail: grazyna.razik@ciniba.edu.pl

iD https://orcid.org/0000-0001-9059-6183

\section{The RE-BUŚ Repository as a place of scholarly output dissemination for the University of Silesia academic employees Announcement}

\begin{abstract}
The Open Access Movement has been on the increase and gaining popularity among contributors, but also editorial boards of journals and authors of monographs. Such undeniable advantages of Open Access as enhancing the availability and the impact factor of their works, encourages authors to utilize this form of publishing, also by actively searching for places where their texts will be made available. Designed to meet these expectations are repositories which gather and store texts and data, in order to make it accessible to wide spectre of audience. This article aims at popularizing and promoting the RE-BUŚ Repository of the University of Silesia as a database set up to increase the visibility of the University employees' output.
\end{abstract}

Keywords: Creative Commons. Open Access. The RE-BUŚ Repository of the University of Silesia in Katowice 